\title{
$P$ fimbriae, capsule and aerobactin characterize colonic resident Escherichia coli
}

\author{
F. NOWROUZIAN*, I. ADLERBERTH AND A. E. WOLD \\ Department of Clinical Immunology, Göteborg University, Sweden
}

(Accepted 13 September 2000)

\section{SUMMARY}

Resident and transient Escherichia coli strains from the colonic microflora of 13 Swedish schoolgirls were analysed for carriage of genes encoding a range of adhesins $(\mathrm{P}$, type 1 and $\mathrm{S}$ fimbriae, Dr haemagglutinin and three varieties of the $\mathrm{P}$ fimbrial papG adhesin) and other virulence traits (K1 and K5 capsule, haemolysin and aerobactin) using multiplex PCR. Fortyfour percent of the resident clones carried genes for $\mathrm{P}$ fimbriae, $\mathrm{K} 1$ or $\mathrm{K} 5$ capsule, and aerobactin, compared with only $3 \%$ of transient clones $(P<0 \cdot 0001)$. The P-fimbriated clones most often had the class II variety of the P-fimbrial adhesin gene papG and this adhesin was significantly associated with persistence of a strain. S fimbriae and type 1 fimbriae were equally common in resident and transient strains. The results indicate that not only $\mathrm{P}$ fimbriae, but also, certain capsules and the ability to produce the siderophore aerobactin might contribute to persistence of $E$. coli in the large intestine.

\section{INTRODUCTION}

Escherichia coli is a member of the normal intestinal microflora of man and other mammals [1]. Certain $E$. coli strains may spread from their normal niche in the colon and cause extra-intestinal infections such as urinary tract infection and septicaemia [2,3]. Such pathogenic E. coli isolates often express a range of virulence factors, including adhesins which confer binding to host cell structures, certain $\mathrm{O}$ and $\mathrm{K}$ antigens which contribute to protection against phagocytes and complement-mediated lysis, production of the iron-trapping compound aerobactin, and secretion of the cytolytic toxin haemolysin [4].

E. coli strains differ in their capacity to persist in the normal colonic microflora. Resident strains may colonize an individual for months or years $[5,6]$ while

\footnotetext{
* Author for correspondence: Department of Clinical Immunology, Guldhedsgatan 10, S-413 46 Göteborg, Sweden.
}

transient strains are found only once, or on a few occasions closely spaced in time in an individual's intestine $[5,6]$. We and others have shown that resident $E$. coli strains more often than transient strains express $P$ fimbriae [7-9], previously recognized as the most important virulence factor for pyelonephritis [10]. P fimbriae, which bind to the Gal $\alpha 1 \rightarrow 4 \mathrm{Gal} \beta$ disaccharide, confer binding not only to urinary tract epithelial cells [11] but also to colonic epithelium $[12,13]$.

The Gal $\alpha 1 \rightarrow 4 \mathrm{Gal} \beta$ binding adhesin of $\mathrm{P}$ fimbriae, papG, occurs in three recognized variants, termed class I-III. All three papG classes bind to $\mathrm{Gal} \alpha 1 \rightarrow 4 \mathrm{Gal} \beta$ containing glycolipids in the globoseries but have slightly different receptor specificities $[14,15]$. The class I adhesin primarily binds globotriaosylceramide $\left(\mathrm{GbO}_{3}\right)$, while class II recognizes globoside $\left(\mathrm{GbO}_{4}\right)$ and class III the Forssman glycolipid $\left(\mathrm{GbO}_{5}\right)$. No information is available concerning the role of the different P-fimbrial adhesins for intestinal 
persistence. In addition, a range of other E. coli adhesins, such as S fimbriae and Dr haemagglutinin, confer binding to human intestinal epithelial cells [13]. They could therefore contribute to intestinal persistence.

In a gnotobiotic rat model, in which two isogenic E. coli strains differing only in expression of the K5 capsule were allowed to compete for establishment in the normal intestinal microflora, the encapsulated strain had an advantage [16]. Similarly, an E. coli strain with smooth LPS colonized better in antibiotictreated mice than its rough mutant [17]. This implies that other virulence factors than adherence may play a role in the competition between E. coli strains in the intestinal microflora.

In the present study, we examined a collection of resident and transient colonic E. coli strains from the large intestinal microflora of Swedish schoolgirls [7] for their carriage of a range of virulence genes. To this end, a set of multiplex PCR analyses were developed for identification of the genes for $\mathrm{P}, \mathrm{S}$ and type 1 fimbriae, Dr haemagglutinin, the K1 and K5 capsular phenotypes, haemolysin and aerobactin. We also determined the papG adhesin class of the P-fimbriated isolates. The presence of each of these virulenceassociated genes was compared between resident and transient strains.

\section{MATERIALS AND METHODS}

\section{Bacterial strains}

Twenty-five strains of $E$. coli isolated consistently and 38 strains isolated transiently in a longitudinal study of the rectal flora of 13 Swedish schoolgirls were studied [7]. The girls were identified as having asymptomatic bacteriuria during a school screening programme in the early 1970s and culturing of their rectal flora was performed at every visit to the outpatient clinic, usually every third month [18]. Three colonies were selected at random from each culture and identified as E. coli by limited biotyping. Each isolate was subjected to multilocus enzyme electrophoresis and assigned an electromorphic type (ET) based on the electromorphs for each of 12 loci tested [7]. Isolates from the same host that shared the same ET were defined as belonging to a single strain. Strains found more than once in the same host were designated resident while strains isolated on a single sample occasion were defined as transient. The resident strains had a mean persistence time in the rectal flora of at least 120 days. Nineteen percent of the resident strains expressed $\mathrm{P}$ fimbriae, as shown by agglutination of $\mathrm{Gal} \alpha 1 \rightarrow 4 \mathrm{Gal} \beta$ coated latex beads, whereas this was true for only $2 \cdot 6 \%$ of the transient strains [7].

For development of multiplex PCR to identify a range of virulence genes, the following $E$. coli strains which had previously been genotypically and/or phenotypically characterized with respect to their virulence factors served as positive controls. For P fimbriae: strain 506 MR (class I adhesin) of serotype O19,22: K1: $\mathrm{H}^{-}$[19], strain HU734 (class II adhesin) of serotype $\mathrm{O} 75: \mathrm{K} 5: \mathrm{H}^{-}$[19] and strain HB101/ pPAP $^{601}$ (class III adhesin) of serotype OR:K12 [15]; for S fimbriae: HB101 (PAZZ 50) (sfaII) [20] and HB101 (PANN 801-13) (sfaI), both K12 transformant strains of serotype OR:K12 [21]; for Dr haemagglutinin: C33 [22] and IH 11033 [23] of serotype $\mathrm{O} 75: \mathrm{K} 5: \mathrm{H} 1$ and strain C64 of serotype O75:K5: $\mathrm{H}^{-}$ [22] and for type 1 fimbriae: strain HU734 [19]. As positive controls for $\mathrm{K} 1$ capsule we used the strains 2822 (B2b) of serotype O16:K1 and 2806 (A3I) of serotype $\mathrm{O} 21: \mathrm{K} 1$ isolated from the intestinal microflora of Pakistani infants [24] and for K5 capsule the strains RZ513 of serotype O6:K5 [25] and 2822 (C1b1) of serotype O6:K5 [24]. For aerobactin the strains RZ513 [25] and 29423 (CCUG) were used and for haemolysin the strains RZ513 [25] and 2806 (A3I) [24].

\section{Primers for multiplex PCR}

Virulence factor genes were identified by PCR using the primers listed in Table 1. The primers for the $\mathrm{P}$ fimbrial papC gene and for $\mathrm{S}$ fimbriae have previously been published [26], as well as the primer pairs specific for the three pap $G$ adhesin varieties class I, class II and class III [27]. For aerobactin and haemolysin, we used previously published primers amplifying DNA fragments of the iut $A$ [28] and $h l y A$ genes [29], respectively.

Primers for type 1 fimbriae, Dr haemagglutinin, and the capsular antigens $\mathrm{K} 1$ and $\mathrm{K} 5$ were designed by us using the computer Oligo Primer Analysis Software (version 5.0). These primer pairs amplified sequences of the fim $A$ gene in the type 1 fimbrial operon, the $d r a A$ gene in the Dr operon, the neuB gene in the $\mathrm{K} 1$ operon and the $k f i C$ gene in the $\mathrm{K} 5$ operon, respectively. Primers were designed and selected to avoid formation of dimers and to give PCR products sufficiently varying in size to allow separation of PCR products in gel electrophoresis (Table 1). 
Table 1. Primers used for detection of $\mathrm{E}$. coli virulence factors genes

\begin{tabular}{|c|c|c|c|c|c|}
\hline $\begin{array}{l}\text { Virulence } \\
\text { factor }\end{array}$ & Gene & Primer sequence $\left(5^{\prime}-3^{\prime}\right)$ & Designation & $\begin{array}{l}\text { Size of the } \\
\text { PCR products }\end{array}$ & Reference \\
\hline P fimbriae & papC & $\begin{array}{l}\text { GACGGCTGTACTGCAGGGTGTGGCG } \\
\text { ATATCCTTTCTGCAGGGATGCAATA }\end{array}$ & $\begin{array}{l}\text { pap } 1 \\
\text { pap } 2\end{array}$ & $328 \mathrm{bp}$ & {$[26]$} \\
\hline $\begin{array}{l}\text { papG adhesin } \\
\text { 'Class I' }\end{array}$ & papG & $\begin{array}{l}\text { TCGTGCTCAGGTCCGGAATTT } \\
\text { TGGCATCCCCCAACATTATCG }\end{array}$ & $\begin{array}{l}\text { j96-193f } \\
\text { j96-653r }\end{array}$ & $461 \mathrm{bp}$ & {$[27]$} \\
\hline $\begin{array}{l}\text { papG adhesin } \\
\text { 'Class II' }\end{array}$ & $\operatorname{pap} G$ & $\begin{array}{l}\text { GGGATGAGCGGGCCTTTGAT } \\
\text { CGGGCCCCCAAGTAACTCG }\end{array}$ & $\begin{array}{l}\text { ia2-383f } \\
\text { ia2-572r }\end{array}$ & 196 bp & {$[27]$} \\
\hline $\begin{array}{l}\text { papG adhesin } \\
\text { 'Class III' }\end{array}$ & papG & $\begin{array}{l}\text { GGCCTGCAATGGATTTACCTGG } \\
\text { CCACCAAATGACCATGCCAGAC }\end{array}$ & $\begin{array}{l}\text { prs-198f } \\
\text { prs-455r }\end{array}$ & $258 \mathrm{bp}$ & {$[27]$} \\
\hline S fimbriae & $\begin{array}{l}\text { sfaD } \\
\text { sfaE }\end{array}$ & $\begin{array}{l}\text { CTCCGGAGAACTGGGTGCATCTTAC } \\
\text { CGGAGGAGTAATTACAAACCTGGCA }\end{array}$ & $\begin{array}{l}\text { sfa } 1 \\
\text { sfa } 2\end{array}$ & $410 \mathrm{bp}$ & {$[26]$} \\
\hline Type 1 fimbriae & $\operatorname{fim} A$ & $\begin{array}{l}\text { CGACGCATCTTCCTCATTCTTCT } \\
\text { ATTGGTTCCGTTATTCAGGGTTGTT }\end{array}$ & $\begin{array}{l}\text { type } 1-331 f \\
\text { type } 1-1052 \mathrm{r}\end{array}$ & $721 \mathrm{bp}$ & This study \\
\hline Dr haemagglutinin & $\operatorname{draA}$ & $\begin{array}{l}\text { GCCAACTGACGGACGCAGCAC } \\
\text { CCCCAGCTCCCGACATCGTTTTT }\end{array}$ & $\begin{array}{l}\text { Dr-321f } \\
\text { Dr-550r }\end{array}$ & $229 \mathrm{bp}$ & This study \\
\hline Capsule K1 & пеив & $\begin{array}{l}\text { CTACCCCTTTTGACGAAGAC } \\
\text { ACACACCTGACCCCAATAC }\end{array}$ & $\begin{array}{l}\text { K1-1011f } \\
\text { K1-1504r }\end{array}$ & 493 bp & This study \\
\hline Capsule K5 & $k f i C$ & $\begin{array}{l}\text { GCCACCAACTGTCGCAAAA } \\
\text { TGTCGCCCAAACAAAAAGATT }\end{array}$ & $\begin{array}{l}\text { K5-1756f } \\
\text { K5-2564r }\end{array}$ & 809 bp & This study \\
\hline Aerobactin & iut $A$ & $\begin{array}{l}\text { GGCTGGACATCATGGGAACTGG } \\
\text { CGTCGGGAACGGGTAGAATCG }\end{array}$ & $\begin{array}{l}\text { aer-851f } \\
\text { aer-1152r }\end{array}$ & $301 \mathrm{bp}$ & {$[28]$} \\
\hline Haemolysin & $h l y A$ & $\begin{array}{l}\text { AACAAGGATAAGCACTGTTCTGGCT } \\
\text { ACCATATAAGCGGTCATTCCCGTCA }\end{array}$ & $\begin{array}{l}\text { hly1 } \\
\text { hly2 }\end{array}$ & 1177 bp & [29] \\
\hline
\end{tabular}

* f, forward; r, reverse.

Three separate multiplex PCRs were carried out as described below. The first PCR included primer pairs for type 1, $\mathrm{P}$ and $\mathrm{S}$ fimbriae as well as $\mathrm{Dr}$ haemagglutinin. Another PCR included primer pairs for the three papG alleles. A third multiplex PCR detected the genes for haemolysin, aerobactin and the capsular antigens $\mathrm{K} 1$ and $\mathrm{K} 5$.

\section{DNA preparation and amplification procedure}

A small amount of bacteria was picked with the tip of a sterile syringe directly from an agar-grown colony and suspended in $50 \mu \mathrm{l}$ PCR reaction mixture in an autoclaved thin-wall reaction tube (Perkin-Elmer, Foster City, CA). The mixture contained 1.5 or $2.0 \mathrm{mM} \mathrm{MgCl}_{2}$ (Perkin-Elmer), the higher concentration being used in the PCR identifying the genes for haemolysin, aerobactin and the capsular antigens K1 and $\mathrm{K} 5,0.1 \mathrm{~mm}$ each of the four deoxynucleoside triphosphates (Perkin-Elmer) and $0.45 \mu \mathrm{M}$ of each primer pair. A drop of mineral oil (Perkin-Elmer) was overlaid and the mixture was heated to $94{ }^{\circ} \mathrm{C}$ for 10 min (Cetus Model 480 Thermocycler, PerkinElmer) to disrupt the bacteria and release their DNA.
After cooling to $80^{\circ} \mathrm{C}, 2 \mathrm{U} / \mu \mathrm{l}$ Taq-polymerase (Perkin-Elmer) was added and the PCR reaction was run using the following temperature profile: an initial denaturation at $94{ }^{\circ} \mathrm{C}$ for 4 min was followed by 25 cycles of denaturation at $94{ }^{\circ} \mathrm{C}$ for $2 \mathrm{~min}$, annealing at $65^{\circ} \mathrm{C}$ for $1 \mathrm{~min}$ and extension at $72{ }^{\circ} \mathrm{C}$ for $2 \mathrm{~min}$ and a final extension at $72{ }^{\circ} \mathrm{C}$ for $3 \mathrm{~min}$. The PCR products were separated by electrophoresis in a $2 \%$ agarose gel (No. A-9539, Sigma, St Louis, MO). The electrophoresis was run in Tris-Borate-EDTA buffer, $\mathrm{pH} 8.3$ $(0.445 \mathrm{~m}$ Tris borate, $0.01 \mathrm{~m}$ EDTA) at a constant voltage of $120 \mathrm{~V}$ for $2.5 \mathrm{~h}$. A DNA marker (VIII $0.5 \mu \mathrm{g}$, Boehringer-Mannheim, Bromma, Sweden) was used as molecular size standard. The gel was stained with $0.5 \mu \mathrm{g} / \mathrm{ml}$ ethidium bromide (E-1510, Sigma) and photographed under UV light (Polaroid MP4 instant camera system, Polaroid).

\section{Phenotypic expression of virulence factors in $E$. coli}

Phenotypic expression of $E$. coli adhesins was tested by hemagglutination using 3\% suspensions in PBS of human, ox and horse erythrocytes with and without $2.5 \%$ methyl- $\alpha$-D-mannoside. A loopful of bacteria 
was mixed with one drop of an erythrocyte suspension and haemagglutination (HA) was read by the naked eye after gentle tilting of the slide for $3 \mathrm{~min}$. Agglutination of human or ox erythrocytes in the absence and presence of methyl- $\alpha$-D-mannoside was designated mannose-resistant HA, while agglutination of horse erythrocytes in the absence, but not in the presence of methyl- $\alpha$-D-mannoside was defined as mannose-sensitive HA.

Capsule serotyping was performed against 67 capsule antigens at the Statens Serum Institut, Copenhagen, Denmark (personal communication).

Production of $\alpha$-haemolysin was detected by the presence of a $\alpha$-haemolytic zone around the bacterial colony on nutrient agar containing $5 \%$ horse erythrocytes [18].

Secretion of aerobactin was assessed by the ability to promote growth of an aerobactin-requiring E. coli strain LG 1522 [30].

\section{Statistical methods}

Comparisons of proportions were performed using Fisher's exact test.

\section{RESULTS}

\section{Genes for adhesins in resident and transient $E$. coli} strains

Figure 1 shows the results of a multiplex PCR using primer pairs detecting genes for $\mathrm{P}, \mathrm{S}$, and type 1 fimbriae and Dr haemagglutinin in E. coli.

The frequency in 25 resident and 38 transient $E$. coli strains of different fimbrial or adhesin genes is shown in Table 2. The papC gene in the operon encoding $\mathbf{P}$ fimbriae was seven times more frequent among resident than transient colonic E. coli strains (14/25 vs. $3 / 38, P<0.0001)$. The 17 papC-positive strains were analysed for their adhesin variety. Eleven strains $(65 \%)$ had the class II type of the papG adhesin and one $(6 \%)$ had the class III type. None had the class I variety and five papC-positive strains (29\%) failed to amplify any DNA fragment specific for the papG gene with the primers used. Carriage of the gene for the class II variety of the $\mathrm{Gal} \alpha 1 \rightarrow 4 \mathrm{Gal} \beta$ specific adhesin was significantly associated with intestinal persistence (Table 2).

Genes for S fimbriae were carried by approximately $20 \%$ of both resident and transient strains and type 1

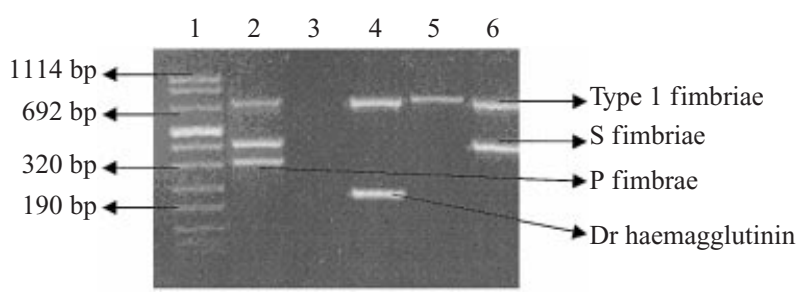

Fig. 1. Detection of genes for type 1, S, and P fimbriae and Dr haemagglutinin in intestinal $E$. coli strains using multiplex PCR. Lane 1, DNA size marker; lanes 2-6, intestinal E. coli strains. PCR products were separated by agarose gel electrophoresis and stained with ethidium bromide.

Table 2. Rates of carriage of adhesin genes in resident and transient colonic E. coli strains

\begin{tabular}{lrcc}
\hline \hline & \multicolumn{2}{c}{$\%$ positive strains } & \\
\cline { 2 - 3 } Adhesins & Resident & Transient & \multirow{2}{*}{$P$ value } \\
\hline P fimbriae & 56 & 8 & $<0 \cdot 0001$ \\
$\quad$ Class I & 0 & 0 & \\
Class II & 40 & 3 & $0 \cdot 0002$ \\
Class III & 4 & 0 & $0 \cdot 39$ \\
$\quad$ None of the above & 12 & 5 & $0 \cdot 37$ \\
S fimbriae & 24 & 16 & $0 \cdot 51$ \\
Type 1 fimbriae & 92 & 74 & $0 \cdot 10$ \\
Dr haemagglutinin & 0 & 0 & \\
\hline \hline
\end{tabular}

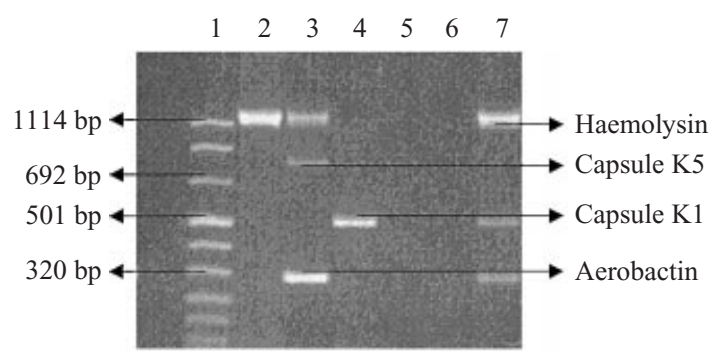

Fig. 2. Detection of genes for the capsular antigens $\mathrm{K} 1$ and $\mathrm{K} 5$, haemolysin and aerobactin in intestinal $E$. coli strains using multiplex PCR. Lane 1, DNA size marker; lanes 2-7, intestinal E. coli strains. PCR products were separated by agarose gel electrophoresis and stained with ethidium bromide.

fimbriae by the great majority of all strains (Table 2). The gene encoding the Dr haemagglutinin was not detected in any of the isolates.

\section{Genes for other pathogenicity factors in resident and transient $E$. coli strains}

Figure 2 depicts a multiplex PCR detecting the genes for haemolysin, aerobactin and the capsular types K1 
Table 3. Carriage of genes encoding capsules, aerobactin and haemolysin in resident and transient colonic E. coli strains

\begin{tabular}{llll}
\hline \hline & \multicolumn{2}{l}{$\%$ positive strains } & \\
\cline { 2 - 3 } Virulence factor & Resident & Transient & $P$ value \\
\hline Capsular antigens & & & \\
$\quad$ K1 & 36 & $5 \cdot 2$ & 0.0045 \\
$\quad$ K5 & 20 & 0 & $0 \cdot 0076$ \\
Other & & & \\
$\quad$ Aerobactin & 64 & 16 & 0.0001 \\
Haemolysin & 32 & 13 & $0 \cdot 11$ \\
\hline \hline
\end{tabular}

and K5. Table 3 shows the frequencies of these factors in resident and transient colonic E. coli isolates. The $n e u B$ gene encoding $\mathrm{K} 1$ capsule formation was seven times more common in resident compared with transient strains $(P=0 \cdot 0045)$. The $k f i C$ gene encoding K 5 capsule was only detected in resident $E$. coli $(P=$ $0.0076)$ and the iutA gene of the aerobactin gene operon was four times more common in resident than in transient strains $(P=0 \cdot 0001)$. There was no significant difference in carriage of the $h l y A$ gene coding for haemolysin between resident and transient strains.

\section{Capsular types other than K1 and K5}

As $\mathrm{K} 1$ and $\mathrm{K} 5$ appeared to be associated with persistence, capsular typing was performed on all strains using antisera to a large variety of capsular phenotypes. $\mathrm{K} 1$ and $\mathrm{K} 5$ were the most frequent capsular types, found together in 11/63 strains (17\%), while other phenotypes such as K7 (2 strains), K51 (2 strains), K2, K13, K29, K43 (1 strain each), and K positive but non-typable comprised 19 of 63 strains $(30 \%)$. There was no apparent association between capsules other than $\mathrm{K} 1$ and $\mathrm{K} 5$ and persistence of a strain. Thus, $38 \%$ of resident strains and $60 \%$ of transient strains had capsules other than K1 or K5, including those that were non-typable.

\section{Combination of pathogenicity traits in resident and transient $E$. coli}

Pathogenicity factors tend to appear in combinations. Indeed, $71 \%$ of papC-positive clones had the aerobactin gene compared with only $17 \%$ of the papCnegative clones $(P=0.0001)$. Similarly, $47 \%$ and $24 \%$ of pap $C$-positive clones had the $\mathrm{K} 1$ or $\mathrm{K} 5$ genes, respectively, whereas this was true for 7 and $2 \%$ of the pap $C$-negative clones $(P=0.0006$ for $\mathrm{K} 1$ and $P=$ 0.016 for K5).

The combinations of the putative colonization factors $\mathrm{P}$ fimbriae, $\mathrm{K} 1$ or $\mathrm{K} 5$ capsule and aerobactin in resident and transient clones are shown in Table 4. Eleven $(44 \%)$ of the 25 resident clones carried a combination of all 3 factors and 13 resident strains $(52 \%)$ had at least 2 of them. This was true for only 1 of $38(2.6 \%)$ transient strains $(P<0.0001)$.

$\mathrm{K} 1$ capsule was associated with $\mathrm{O} 1, \mathrm{O} 2, \mathrm{O} 7$ or rough LPS phenotypes while $\mathrm{K} 5$ capsule occurred in combination with serogroups $\mathrm{O} 6, \mathrm{O} 10, \mathrm{O} 18$ and $\mathrm{O} 25$. A large variety of different $\mathrm{O}$ antigens was found among the mainly transient strains which had neither $\mathrm{P}$ fimbriae, $\mathrm{K} 1$ or K5, or aerobactin genes (Table 4).

We analysed whether $\mathrm{K} 1$ or K5 capsule or aerobactin would be associated with persistence independent of $\mathrm{P}$ fimbriae. Eleven resident and 35 transient strains lacked the papC gene. The $\mathrm{K} 1$ or $\mathrm{K} 5$ capsular genes were carried by $27 \%$ of resident versus $3 \%$ of transient strains in this subgroup $(P=0.06)$. Aerobactin genes were found in $36 \%$ of resident compared with $11 \%$ transient strains devoid of $\mathrm{P}$ fimbrial genes $(P=0 \cdot 08)$. All resident strains lacking the papC gene carried the fim $A$ type 1 fimbrial gene ( $P=0.08$ compared to transient strains).

\section{Phenotypic expression of pathogenicity factors in $E$. coli strains}

The phenotypic expression of pathogenicity traits was examined. Fifty-five percent of papC-positive isolates expressed mannose-resistant agglutination of human erythrocytes, $55 \%$ of the strains carrying the neuB gene were serologically positive for K1 and $100 \%$ of $\mathrm{kfiC}$ positive strains reacted with anti-K5 antisera. Aerobactin production was noted in $95 \%$ of clones carrying the iutA gene and production of $\alpha$ haemolysin in $46 \%$ of those carrying the hlyA gene. No differences was observed in phenotypic expression of traits in genotypically positive isolates related to whether the strains were resident or transient.

\section{DISCUSSION}

In the present study we investigated whether various bacterial traits, previously characterized as pathogenic properties required for extra-intestinal disease, were associated with persistence of $E$. coli in its natural ecological niche, the large intestine. Resident and transient E. coli strains from the large bowel microflora of Swedish schoolgirls were analysed for the 
Table 4. Carriage of different combinations of virulence genes in resident and transient $\mathrm{E}$. coli strains

\begin{tabular}{|c|c|c|c|}
\hline \multirow[b]{2}{*}{$\begin{array}{l}\text { Virulence factor } \\
\text { combination }\end{array}$} & \multicolumn{2}{|c|}{ No. of strains } & \multirow[b]{2}{*}{ O serogroups (no. of strains) } \\
\hline & $\begin{array}{l}\text { Resident } \\
(n=25)\end{array}$ & $\begin{array}{l}\text { Transient } \\
(n=38)\end{array}$ & \\
\hline $\mathrm{P}+\mathrm{K} 1+$ aerobactin & 7 & 1 & $\mathrm{O} 1(3), \mathrm{O} 7(2), \mathrm{OR}^{*}(2), \mathrm{O} 2$ \\
\hline $\mathrm{P}+\mathrm{K} 5+$ aerobactin & 4 & 0 & $\mathrm{O} 18(2), \mathrm{O} 10, \mathrm{O} 6$ \\
\hline $\mathrm{K} 1+$ aerobactin & 1 & 0 & $\mathrm{O} 1$ \\
\hline $\mathrm{K} 5+$ aerobactin & 1 & 0 & $\mathrm{O} 25$ \\
\hline P fimbriae & 3 & 2 & O1, O8, O75, ONT†, OR \\
\hline K1 & 1 & 1 & OR (2) \\
\hline Aerobactin & 2 & 4 & $\mathrm{O} 9$ (2), O27(2), O4, O8 \\
\hline $\begin{array}{l}\text { Neither P fimbriae, nor } \\
\text { K1, K } 5 \text { or aerobactin }\end{array}$ & 6 & 30 & $\begin{array}{l}\text { OR (5), O } 20(4), \mathrm{O} 79(3), \mathrm{ONT}(3), \mathrm{O} 3(2), \\
\text { O } 98(2), \mathrm{O} 1, \mathrm{O} 4, \mathrm{O} 5, \mathrm{O} 6, \mathrm{O} 9, \mathrm{O} 13, \\
\mathrm{O} 22, \mathrm{O} 28, \mathrm{O} 40, \mathrm{O} 44, \mathrm{O} 53, \mathrm{O} 77, \\
\mathrm{O} 112, \mathrm{O} 136, \mathrm{O} 146, \mathrm{O} 147, \mathrm{O} 160\end{array}$ \\
\hline
\end{tabular}

* OR, rough strain; $\uparrow$ ONT, O antigen positive, but non-typable.

presence of virulence-associated genes using multiplex PCR with specific primers.

Genes encoding P fimbriae were detected in $56 \%$ of resident strains, which was seven times more common than in transient $E$. coli strains. When the set of strains examined here were previously assessed for phenotypic expression of Gal $\alpha 1 \rightarrow 4 \mathrm{Gal} \beta$ binding, resident strains were positive six times more often than transient, but still only $19 \%$ expressed $\mathrm{P}$ fimbriae [7]. Thus, phenotypic expression considerably underestimated gene carriage rates. As both expression of type 1 [31] and S fimbriae (unpublished observations) have been shown to increase in the intestinal environment, this could also be true of $\mathrm{P}$ fimbriae. The high carriage rate among resident strains of genes for $\mathrm{P}$ fimbriae indicate their major importance for intestinal colonization and persistence. $\mathrm{P}$ fimbriae have also been shown to facilitate intestinal colonization in a gnotobiotic rat model in which germ free rats were colonized with isogenic strains, differing in fimbrial expression [32].

The class II variety of the papG adhesin was most frequent among P-fimbriated strains and was also associated with persistence, while the class III variety, previously called prs, was rare and the class I variety was not found. A similar distribution of pap $G$ varieties among intestinal E. coli has previously been reported [33]. Almost one third of papC-positive strains did not yield any PCR product from the papG gene. Such strains could either have previously undefined adhesin variants or completely lack papG gene.

$\mathrm{S}$ fimbriae which are virulence factors for neonatal sepsis and meningitis also adhere to human colonic epithelium [13]. Despite this, genes encoding $\mathrm{S}$ fimbriae were no more prevalent among resident than transient $E$. coli strains. It therefore seems as if mere capacity to adhere to intestinal epithelial cells is insufficient to enable long-term persistence in the gut but rather that the adhesin specificity is of major importance [34]. In accordance, two isogenic strains differing only in carriage of the sfaII gene colonized equally well in a gnotobiotic rat model (unpublished observations). No strains were found that carried the genes for $\mathrm{Dr}$ haemagglutinin which also confers adherence to human intestinal epithelium [13].

Type 1-fimbrial genes were carried by almost all resident $E$. coli strains and by the vast majority of transient strains. The mannose-specific adhesin of type 1 fimbriae mediates binding both to colonic epithelial cells $[12,13]$ and to the carbohydrate chains of secretory IgA, a molecule which is abundant in intestinal secretions [35]. The fact that persons lacking secretory $\operatorname{IgA}$ are less often colonized by type 1fimbriated E. coli [36], suggests that type 1 fimbriae are of ecological importance in the colonic niche in immunocompetent individuals, but phenotypic expression of type 1 fimbriae has previously not been shown to be associated with persistence [7-9]. However, the genes for type 1 fimbriae might be important for persistence of strains devoid of P fimbriae. Thus, all resident strains which did not have $\mathrm{P}$ fimbriae carried the genes for type 1 fimbriae.

The clones which seemed especially apt to colonize the human large intestine did not only carry P-fimbrial genes, but also more often the genes for capsules of the $\mathrm{K} 1$ and $\mathrm{K} 5$ types as well as the siderophore 
aerobactin. A combination of these three traits occurred in almost half of the resident E. coli, but only in a single transient isolate of 38 tested. In strains lacking genes for $\mathrm{P}$ fimbriae, there was an overrepresentation of genes for capsule and aerobactin among resident, as compared to transient strains, although the difference did not reach statistical significance. In a gnotobiotic rat model in which germ-free rats were colonized simultaneously by two isogenic strains both having type 1 as well as $\mathrm{P}$ fimbriae but differing in K5 expression, the K5positive strains colonized at much higher levels than the capsule-negative mutant [16]. Capsules render the bacterial surface hydrophilic and negatively charged $[37,38]$ which makes the bacterium resistant to entrappment in mucus [39]. An efficient sequestration of iron could confer a competitive advantage to aerobactin producing strains in the colonic microflora. In accordance, genes for aerobactin were also significantly more often carried by resident as compared with transient strains in a set of colonic $E$. coli derived from a different age group and geographical region, i.e. Pakistani infants 0-6 months old [40].

We have previously suggested that $\mathrm{P}$ fimbriae may have evolved to increase the persistence of $E$. coli in its normal habitat, the large intestine [7,9]. Other virulence-associated traits may as well primarily contribute to persistence of $E$. coli clones in the intestine. Secondarily, clones persisting in the large intestine for extended periods of time and reaching high population numbers may more easily spread to the urinary tract. In this case, virulence might be 'coincidental' to an adaptation to the colonic niche as has previously been suggested [41].

\section{ACKNOWLEDGEMENTS}

The present study was supported by the Swedish Medical Research Council (No. K98-06X-12612-01A) by the Swedish Association For Research on Agriculture and Forestry, and by the Medical Faculty of Göteborg University. We thank Dr Jörg Hacker, Dr Gabriele Blum-Oehler, Dr Nicklas Strömberg and Dr Timho Korhonen for generously providing E. coli strains.

\section{REFERENCES}

1. Cooke EM, Ewins SP. Properties of strains of Escherichia coli isolated from a variety of sources. J Med Microbiol 1975; 8: 107-11.
2. Vosti KL, Goldberg LM, Monto AS, Rantz LA. Hostparasite interaction in patients with infections due to Escherichia coli. I. The serogrouping of E. coli from intestinal and extraintestinal sources. J Clin Invest 1964; 43: 2377-85.

3. Grüneberg RN. Relationship of infecting urinary organism to the faecal flora in patients with symptomatic urinary infection. Lancet 1969; ii: 766-70.

4. Johnson JR. Virulence factors in Escherichia coli urinary tract infection. Clin Microbiol Rev 1991; 4: $80-128$.

5. Sears HJ, Brownlee I. Persistence of individual strains of Escherichia coli in the intestinal tract of man. J Bacteriol 1949; 59: 299-301.

6. Sears HJ, Brownlee I. Further observations on the persistence of individual strains of Escherichia coli in the intestinal tract of man. J Bacteriol 1951; 63: 47-57.

7. Wold AE, Caugant DA, Lidin-Janson G, Man PD, Svanborg C. Resident colonic Escherichia coli strains frequently display uropathogenic characteristics. J Infect Dis 1992; 165: 46-52.

8. Tullus K, Kühn I, Ørskov I, Ørskov F, Möllby R. The importance of $\mathrm{P}$ and type 1 fimbriae for the persistence of Escherichia coli in the human gut. Epidemiol Infect 1992; 108: 415-21.

9. Adlerberth I, Svanborg C, Carlsson B, et al. P fimbriae and other adhesins enhance intestinal persistence of Escherichia coli in early infancy. Epidemiol Infect 1998; 121: 599-608.

10. Svanborg-Edén C, Hanson LÅ, Jodal U, Lindberg U. Variable adherence to normal human urinary-tract epithelial cells of Escherichia coli strains associated with various forms of urinary-tract infection. Lancet 1976; iv: 490-2.

11. Leffler H, Svanborg-Edén C. Glycolipid receptors for uropathogenic Escherichia coli on human erythrocytes and uroepithelial cells. Infect Immun 1981; 34: 920-9.

12. Wold AE, Thorssén M, Hull S, Svanborg Edén C. Attachment of Escherichia coli via Mannose- or $\mathrm{Gal} \alpha 1 \rightarrow 4 \mathrm{Gal} \beta$-containing receptors to human colonic epithelial cells. Infect Immun 1988; 56: 2531-7.

13. Adlerberth I, Hanson LA, Svanborg C, Svennerholm AM, Nordgren S, Wold AE. Adhesins of Escherichia coli associated with extraintestinal pathogenicity confer binding to colonic epithelial cells. Microb Pathogen 1995; 18: 373-85.

14. Senior D, Baker N, Cedergren B, et al. Globo-A - a new receptor specificity for attaching Escherichia coli. FEBS Lett 1988; 237: 123-7.

15. Strömberg N, Marklund BI, Lund B, et al. Hostspecificity of uropathogenic Escherichia coli depends on differences in binding specificity to Gal $\alpha 1-4$ Gal-containing isoreceptors. EMBO J 1990; 9: 2001-10.

16. Herías MV, Midtvedt T, Hanson LA, Wold AE. Escherichia coli K5 capsule expression enhances colonization of the large intestine in the gnotobiotic rat. Infect Immun 1997; 65: 531-6.

17. Licht TR, Krogfelt KA, Choen PS, Poulsen LK, Urbance J, Molin S. Role of lipopolysaccharide in 
colonization of the mouse intestine by Salmonella typhimurium studied by in situ hybridization. Infect Immun 1996; 64: 3811-7.

18. Lidin-Janson G, Falsen E, Jodal U, Kaijser B, Lincoln K. Characteristics of antibiotic-resistant Escherichia coli in the rectum of healthy school-children. $\mathrm{J}$ Med Microbiol 1977; 10: 299-308.

19. Hagberg L, Hull R, Hull S, Falkow S, Freter R, Svanborg-Edén C. Contribution of adhesion to bacterial persistence in the mouse urinary tract. Infect Immun 1983; 40: 265-72.

20. Hacker J, Kestler H, Hoschützky H, Jann K, Lottspeich F, Korhonen TK. Cloning and characterization of the S fimbrial adhesin II complex of an Escherichia coli O18:K1 meningitis isolate. Infect Immun 1993; 61: 544-50.

21. Hacker J, Schmidt G, Hughes C, Knapp S, Marget M, Goebel W. Cloning and characterization of genes involved in production of mannose-resistant, neuraminidase-susceptible $(\mathrm{X})$ fimbriae from a uropathogenic O6:K15:H31 Escherichia coli strain. Infect Immun $1985 ; 47: 434-40$.

22. Nowicki B, Svanborg-Edén C, Hull R, Hull S. Molecular analysis and epidemiology of the Dr hemagglutinin of uropathogenic Escherichia coli. Infect Immun 1989; 57: 446-51.

23. Väisänen-Rhen V. Fimbriae-like haemagglutinin of Escherichia coli 075 strains. Infect Immun 1984; 46: 401-7.

24. Adlerberth I. Bacterial adherence and intestinal colonization in newborn infants [thesis]. Göteborg, Sweden: Göteborg University, 1996.

25. Zingler G, Blum G, Falkenhagen U, et al. Clonal differentiation of uropathogenic Escherichia coli isolates of serotype O6: K 5 by fimbrial antigen typing and DNA long-range mapping techniques. Med Microbiol Immunol 1993; 182: 13-24.

26. Le Bouguenec C, Archambaud M, Labigne A. Rapid and specific detection of the pap, afa, and sfa adhesinencoding operons in uropathogenic Escherichia coli strains by polymerase chain reaction. J Clin Microbiol 1992; 30: 1189-93.

27. Johnson JR, Brown JJ. A novel multiply primed polymerase chain reaction assay for identification of variant pap $G$ genes encoding the $\mathrm{Gal}(\alpha 1-4) \mathrm{Gal}$-binding pap G adhesins of Escherichia coli. J Infect Dis 1996; 173: $920-6$.

28. Johnson JR, Stapleton AE, Russo TA, Scheutz F, Brown JJ, Maslow JN. Characteristics and prevalence within serogroup $\mathrm{O} 4$ of a J96-like clonal group of uropathogenic Escherichia coli $\mathrm{O} 4: \mathrm{H} 5$ containing the class I and class II alleles of papG. Infect Immun 1997; 65: 2153-9.
29. Yamamoto S, Terai A, Yuri K, Kurazono H, Takeda Y, Yoshida O. Detection of urovirulence factors in Escherichia coli by multiplex polymerase chain reaction. FEMS Immunol Med Microbiol 1995; 12: 85-90.

30. Jacobson SH, Hammarlind M, Lidefeldt KJ, Österberg E, Tullus K, Brauner A. Incidence of aerobactinpositive Escherichia coli strains in patients with symptomatic urinary tract infection. Eur J Microbiol Infect Dis 1988; $7:$ : 630-4.

31. Krogfelt KA, McCormick BA, Burghoff RL, Laux DC, Cohen PS. Expression of Escherichia coli F-18 type 1 fimbriae in the streptomycin-treated mouse large intestine. Infect Immun 1991; 59: 1567-8.

32. Herías MV, Midtvedt T, Hanson LA, Wold AE. Role of Escherichia coli $\mathrm{P}$ fimbriae in intestinal colonization in gnotobiotic rats. Infect Immun 1995; 63: 4781-9.

33. Johanson IM, Plos K, Marklund BI, Svanborg C. Pap, pap $G$ and prs $G$ DNA sequences in Escherichia coli from the fecal flora and the urinary tract. Microb Pathogen 1993; 15: 121-9.

34. Wold AE. Role of bacterial adherence in the establishment of the normal intestinal microflora. In: Hanson LA, Yolken RH, eds. Probiotics, other nutritional factors, and intestinal microflora, Nestlé Nutrition Series, vol. 42. Philadelphia: LippincottRaven 1999: 47-61.

35. Wold AE, Mestecky J, Tomana M. Secretory immunoglobulin A carries oligosaccharide receptors for Escherichia coli type 1 fimbrial lectin. Infect Immun 1990; 58: 3073-7.

36. Friman V, Adlerberth I, Connell H, Svanborg C, Hanson LA, Wold AE. Decreased expression of mannose-specific adhesins by Escherichia coli in the colonic microflora of immunoglobulin A-deficient individuals. Infect Immun 1996; 64: 2794-8.

37. Kim KS, Kang JH, Cross AS. The role of capsular antigens in serum resistance and in vivo virulence of Escherichia coli. FEMS Microbiol Lett 1986; 35: 275-8.

38. Cross AS. The biologic significance of bacterial encapsulation. Curr Top Microbiol Immunol 1990; 150: 87-95.

39. Cone RA. Mucus. In: Ogra PL, Mestecky J, Lamm ME, Strober W, Bienenstock J, McGhee JR, eds. Mucosal immunology, 2nd edn. San Diego, London: Academic Press, 1999: 43-62.

40. Nowrouzian F, Wold AE, Adlerberth I. P fimbriae and aerobactin as intestinal colonization factors for Escherichia coli in Pakistani infants. Epidemiol Infect 2001; 126: 19-23.

41. Levin BR, Svanborg-Edén C. Selection and evolution of virulence in bacteria: an ecumenical excursion and modest suggestion. Parasitology 1990; 100: 103-15. 